\title{
O tratamento diferenciado da Fazenda Pública no Processo Falimentar
}

\author{
Luís Armando Saboya Amora ${ }^{1}$ \\ Mellissa Freitas Ribeiro ${ }^{2}$
}

\begin{abstract}
RESUMO: O presente artigo tem por objetivo analisar eventual tratamento diferenciado concedido à Fazenda Pública em processos falimentares, tanto pela legislação quanto pela jurisprudência, e se tais prerrogativas desequilibram o concurso de credores. Para tanto, dedicase às questões de possibilidade de escolha entre a execução fiscal e a habilitação de crédito, da legitimidade do Fisco para propositura da falência e da penhora no rosto dos autos. Por meio de metodologia bibliográfica, abordagem qualitativa e análise crítica, conclui-se que os institutos acima não se sobrepõem ao concurso de credores, devendo-se respeitar a ordem estabelecida em lei.
\end{abstract}

PALAVRAS-CHAVE: Fazenda Pública. Processo Falimentar. Concurso de Credores. Execução Fiscal. Habilitação de Crédito.

\section{Differentiated treatment of the Public Treasury in the Bankruptcy Proceeding}

\begin{abstract}
The purpose of this article is to analyze a possible differentiated treatment granted to the Public Treasury in bankruptcy proceedings, both by legislation and jurisprudence, and if such prerogatives unbalance the creditors' competition. In order, it is dedicated to the questions of possibility of choosing between the tax enforcement and the proof of claim, of the legitimacy of the Treasury to propose bankruptcy and attachment in the file. Through bibliographic methodology, qualitative approach and critical analysis, it is concluded that the institutes above do not overlap with the creditors' competition, and the order established by law must be respected.
\end{abstract}

KEYWORDS: Public Treasury. Bankryptcy Proceeding. Collective Insolvency. Tax Enforcement. Proof of Claim.

\footnotetext{
${ }^{1}$ Mestre em Direito Constitucional, com foco nas relações privadas, pela Universidade de Fortaleza. Graduado em Direito pela Universidade de Fortaleza. E-mail: luissaboya@hotmail.com. Endereço: Av. Almirante Maximiniano da Fonseca, $n^{\circ}$. 421, ap 909, Eng. Luciano Cavalcante, Fortaleza/CE, CEP 60.811.020.

2 Mestranda em Direito Constitucional pela Universidade Federal do Ceará. Graduada em Direito pela Universidade de Fortaleza e em Ciências Contábeis pela Universidade Federal do Ceará. E-mail: mellissafreitasmfr@gmail.com. Endereço: Rua Rafael Tobias, nº. 2909, José de Alencar, Fortaleza/CE, CEP 60.830-105.
} 


\section{Introdução}

A Fazenda Pública possui várias garantias processuais decorrentes da destinação do crédito que tem em seu favor. Por tratar de valor que - em tese - desperta inequívoco interesse público, a legislação brasileira busca dar a tais créditos tratamento diferenciado, permitindo que o Fisco logre êxito em concursos de credores, a exemplo do que acontece nos processos falimentares.

Pode-se citar como um de tais privilégios o fato de a Fazenda Pública estar em posição vantajosa na lista de pagamento dos credores no processo falimentar, encontrando-se atrás apenas dos credores trabalhistas (limitados a valor determinado pela própria lei) e dos credores com garantia real. Diga-se de passagem que, na legislação falimentar anterior, os créditos tributários estavam a frente dos créditos com garantia real.

Ainda que tenha havido essa mudança com a ascensão dos créditos com garantia real na ordem de pagamento, justificada sobretudo pela pressão exercida por instituições financeiras (em regra, as titulares de tais créditos), o legislador buscou conferir à Fazenda Pública outras garantias que lhe dessem segurança tanto para a realização de atos que garantissem o pagamento quanto na própria satisfação de seu crédito.

Além das garantias expressamente previstas em lei, há entendimentos jurisprudenciais que, ao analisar as lacunas deixadas na legislação falimentar, buscaram seguir o conceito de conferir privilégio aos créditos fiscais no concurso de credores, o que revela um tratamento diferenciado para com credores dessa natureza, independente de se tratar de Fazenda Pública municipal, estadual ou federal.

Feitas tais considerações, o presente artigo busca analisar como se dá o tratamento da Fazenda Pública no processo falimentar, considerando-se tanto os dispositivos aplicados ao tema quanto os principais entendimentos jurisprudenciais, estes concentrados nas decisões do Superior Tribunal de Justiça, porquanto instância máxima para a definição de questões legais e delimitação dos precedentes que não envolvam matéria constitucional.

Para tanto, dedica seu primeiro capítulo ao entendimento do Superior Tribunal de Justiça sobre a possibilidade de a Fazenda Pública escolher entre a habilitação de crédito e a execução fiscal. Em seguida, analisa-se o tema da legitimidade da Fazenda Pública para pedir 
a falência de seu devedor. Por fim, é estudada a questão da penhora no rosto dos autos solicitada quando há execuções fiscais que tramitaram em paralelo com processos falimentares.

Tem-se como problemática de pesquisa o questionamento sobre o tratamento diferenciado concedido tanto pela legislação quanto pela jurisprudência à Fazenda Pública no concurso de credores decorrente do processo falimentar, e quais são as limitações impostas a ela quanto à recepção de seu crédito, considerando-se se há privilégios para além do que dispõe a Lei 11.101/2005.

Para tanto, possui como metodologia tipo bibliográfica, mediante consulta a livros, legislação, projetos de leis, revistas, artigos científicos, notícias jornalísticas, materiais, dados oficiais publicados na Internet e, em especial, análise da jurisprudência do STJ acerca da atuação da Fazenda Pública no processo falimentar.

Quanto à natureza ou abordagem, será qualitativa, pois será feita uma análise crítica acerca das reformas e projetos legislativos, bem como das propostas do Poder Judiciário para solucionar a controvérsia sobre a matéria. Quanto à utilização dos resultados, a pesquisa será aplicada, vez que terá como finalidade contribuir para fins práticos, buscando sedimentar a problemática que se propõe trabalhar.

Quanto aos objetivos, o estudo será exploratório, visando o aprimoramento de ideias, a busca e a coleta de informações sobre o tema em questão, podendo servir, ainda, de auxílio e fomento de novas pesquisas, bem como descritivo, propondo a discriminação e explicação dos fenômenos percebidos. Quanto ao método, será utilizado o indutivo, para a análise da atividade dos Poderes Legislativo e Judiciário, aprofundando-se nas reformas legislativas e avanços jurisprudenciais sobre o tema.

\section{A possibilidade de escolha da Fazenda Pública entre a Habilitação de Crédito e a Execução Fiscal}

A primeira controvérsia existente quanto à atuação da Fazenda Pública em processos falimentares diz respeito à sua possibilidade de escolha entre a habilitação de crédito e a execução fiscal para cobrança de seus créditos junto à massa falida. A opção advém da relevância dos créditos tributários e da mudança trazida pela Lei 11.101/05 em relação à ordem dos credores, uma vez que os créditos fiscais eram, antes de sua vigência, os segundos na ordem 
de pagamento concursal, permanecendo atrás apenas dos créditos trabalhistas.

Com a edição da LFRE, os créditos com garantia real passaram à frente dos créditos tributários (mudança realizada pelo Senado no PL da Câmara 71/2003). Antes dela, a regra definida pelo art. 186 da Lei 5.172/1966 (Código Tributário Nacional - CTN) era a de que “o crédito tributário prefere a qualquer outro, seja qual for a natureza ou o tempo da constituição deste, ressalvados os créditos decorrentes da legislação do trabalho” (BRASIL, 1966).

Referida alteração, oriunda da necessidade de geração de crédito no mercado brasileiro, causou controvérsia diante do princípio republicano do interesse público ${ }^{3}$ e da importância da arrecadação do fisco para a viabilização de políticas públicas. No dia 09 de fevereiro de 2005, além da Lei 11.101/05, aprovou-se a Lei Complementar 118, justamente para alterar a redação do CTN referente à preferência dos créditos fiscais. Dita lei, no entanto, manteve a possibilidade de cobrança independente dos créditos tributários, mesmo com a decretação da falência, ampliando-a inclusive à recuperação judicial, conforme disposição do art. 187 do CTN. ${ }^{4} 5$ Segundo Gladston Mamede (2017, p. 44)

O artigo 187 do Código Tributário Nacional, alterado pela Lei Complementar 118/05,
estabelece que a cobrança judicial do crédito tributário não é sujeita a concurso de
credores, portanto, falência, recuperação judicial ou extrajudicial de empresa,
insolvência civil, intervenção e liquidação extrajudicial e, mesmo, inventário ou
arrolamento. A regra aplica-se indistintamente às Fazendas Federal, Estaduais,
Distrital e Municipais, com o que as execuções fiscais manterão seu trâmite em
apartado, sendo que, em se tratando de execução movida pela União, esse trâmite se
fará na Justiça Federal, por força do artigo 109, I, da Constituição da República. No
âmbito específico da falência, no entanto, essa regra não permite à Fazenda
desconhecer o juízo universal e o concurso de credores.

Respaldada por tais modificações, a Fazenda Pública permaneceu cobrando seus créditos por meio de execuções fiscais, fato que suscitou dúvidas em relação a alguns pontos, quais fossem: i) o fisco estaria impossibilitado de cobrar valores abaixo de $\mathrm{R} \$ 10.000,00$ (dez mil

\footnotetext{
${ }^{3}$ Trata-se de princípio que prevê a supremacia do interesse coletivo - ou público - sobre o particular. Segundo Marinela (2013, p. 27), “o princípio da supremacia determina privilégios jurídicos e um patamar de superioridade do interesse público sobre o particular. Em razão desse interesse público, a Administração terá posição privilegiada em face dos administrados, além de prerrogativas e obrigações que não são extensíveis aos particulares”.

${ }^{4}$ Art. 187. A cobrança judicial do crédito tributário não é sujeita a concurso de credores ou habilitação em falência, recuperação judicial, concordata, inventário ou arrolamento. (Redação dada pela Lcp nº 118, de 2005)

${ }^{5}$ A Lei 6.830/1980, Lei de Execuções Fiscais, aponta, de forma semelhante, que “Art. 29 - A cobrança judicial da Dívida Ativa da Fazenda Pública não é sujeita a concurso de credores ou habilitação em falência, concordata, liquidação, inventário ou arrolamento” (BRASIL, 1980).
} 
reais) das massas falidas, conforme art. 20 da Lei 10.522/02? ii) a Fazenda Pública teria a opção de fazer uso da habilitação de crédito ao invés de promover a execução fiscal? iii) a penhora decorrente da execução fiscal permitiria expropriar bens arrecadados pela administradora judicial para satisfação do crédito fazendário? iv) as multas tributárias seriam cobradas na execução fiscal?

Tais questionamentos foram objetos de processos judiciais que chegaram ao julgamento do STJ. Instada a se manifestar nos Recursos Especiais $n^{\circ}$. 185.838/SP, 1.103.405/MG, 988.468/RS, 188.148/RS e 695.167/MS (v.g.), a corte construiu o procedimento a ser adotado pela Fazenda Pública na cobrança de seus créditos e deu o correto entendimento aos arts. 186 e 187 do CTN, além do art. 83 da LFRE.

Destaque, por oportuno, que tais questionamentos são anteriores à Lei 11.101/05, conforme Recursos Especiais $n^{\circ}$. 185/838/SP e 188.148/RS (v.g.). Já em 2001, existiam questionamentos sobre a cobrança de débitos fiscais nos processos de falência e concordata, e o Superior Tribunal de Justiça definia os caminhos a serem seguidos pela Fazenda Pública, uma vez que a Lei Complementar manteve a possibilidade de cobrança independente.

Em relação à primeira dúvida, o STJ tratou de solucioná-la em prol da Fazenda Pública, permitindo-lhe a cobrança de créditos abaixo de $\mathrm{R} \$ 10.000,00$ (dez mil reais). Nesse caso, somente poderia ser feita por meio da habilitação de seu crédito no processo falimentar, o que justifica a possibilidade de escolha pela habilitação de crédito. Desta feita, em que pese a exceção ao juízo universal feita pelo art. 76 da LFRE $^{6}$, permitiu-se ao fisco optar pela habilitação de crédito quando lhe for benéfica, como no caso em que a execução fiscal restar proibida por lei (v.g., art. 20, Lei 10.522/02).

Traçam-se, a partir desse entendimento, as seguintes premissas: i) que as execuções fiscais em andamento não serão suspensas e; ii) que, em relação às cobranças pela Fazenda Pública após a quebra, poderão ser feitas por meio de habilitação ou pela execução, utilizandose do caminho que julgar mais eficiente. Tal possibilidade de escolha, no entanto, não significa dizer que o fisco pode usar as 02 (duas) simultaneamente. Ao escolher um dos ritos, a Fazenda

\footnotetext{
${ }^{6}$ Art. 76. O juízo da falência é indivisível e competente para conhecer todas as ações sobre bens, interesses e negócios do falido, ressalvadas as causas trabalhistas, fiscais e aquelas não reguladas nesta Lei em que o falido figurar como autor ou litisconsorte ativo.
} 
Pública renuncia à utilização do outro, conforme elucidou o STJ no REsp 1.103.405/MG:

PROCESSUAL CIVIL E TRIBUTÁRIO. APRESENTAÇÃO DE CRÉDITOS NA FALÊNCIA. PRESTAÇÃO DE CONTAS APRESENTADA PELO SÍNDICO. CRÉDITOS TRIBUTÁRIOS DE PEQUENO VALOR. HABILITAÇÃO. CASO CONCRETO. POSSIBILIDADE.

1. Não viola o art. 535 do CPC o acórdão que soluciona a controvérsia com base em fundamento prejudicial ao ponto sobre o qual não houve enfrentamento no âmbito do Tribunal de origem.

2. Os arts. 187 e 29 da Lei 6.830/80 não representam um óbice à habilitação de créditos tributários no concurso de credores da falência; tratam, na verdade, de uma prerrogativa da entidade pública em poder optar entre o pagamento do crédito pelo rito da execução fiscal ou mediante habilitação do crédito.

3. Escolhendo um rito, ocorre a renúncia da utilização do outro, não se admitindo uma garantia dúplice. Precedentes.

4. O fato de permitir-se a habilitação do crédito tributário em processo de falência não significa admitir o requerimento de quebra por parte da Fazenda Pública.

5. No caso, busca-se o pagamento de créditos da União, representados por 11 (onze) inscrições em dívida ativa, que, todavia, em sua maioria, não foram objeto de execução fiscal em razão de seu valor. Diante dessa circunstância, seria desarrazoado exigir que a Fazenda Nacional extraísse as competentes CDA's e promovesse as respectivas execuções fiscais para cobrar valores que, por razões de política fiscal, não são ajuizáveis (Lei 10.522/02, art. 20), ainda mais quando o processo já se encontra na fase de prestação de contas pelo síndico.

6. Determinação de retorno dos autos ao Tribunal de origem para verificação da suficiência e validade da documentação acostada pela Procuradoria da Fazenda Nacional para fazer prova de seu pretenso crédito.

7. Recurso especial provido. (SUPERIOR TRIBUNAL DE JUSTIÇA, 2009, online, grifos do autor)

Respondidos os 02 (dois) primeiros questionamentos, passa-se à solução do terceiro. No caso de execução fiscal anterior à falência, a penhora de bens arrecadados pela massa falida garante a adjudicação pelo fisco? A resposta é negativa e foi dada pelo STJ nos julgamentos dos REsps 188.148/RS e 695.167/MS, uma vez que tal fato constituiria burla à ordem de pagamento estipulada pelo art. 83 da Lei 11.101/05. Desta feita, mesmo que vendidos os bens penhorados anteriormente em execução fiscal, os valores arrecadados serão destinados à massa, para que seu administrador organize a ordem de pagamento dos credores.

Destarte, a continuidade da execução fiscal não representa uma garantia de que a Fazenda Pública terá seu crédito adimplido para além do concurso de credores, mas que não será necessária a habilitação do crédito já executado. Todo o montante arrecadado nas execuções fiscais, por sua vez, restará à disposição da administração judicial, que fará uso dele para pagar os credores na ordem estipulada em lei, o que permite se afirmar que a habilitação do crédito é meio mais simples e econômico ao fisco. Nas palavras de Jonatas Vieira de Lima (2012):

Imaginemos uma falência onde todo o ativo do devedor falido já esteja devidamente 
arrecadado pelo juízo falimentar, restando apenas os procedimentos de alienação e posterior pagamento dos credores, segundo a ordem de precedência de seus créditos. Seria interessante de algum modo para a fazenda pública prosseguir com a execução fiscal de forma independente e pedir penhora de bens já arrecadados para promover a sua alienação judicial, sendo que, como já visto, os valores arrecadados nas execuções fiscais devem compor a massa falida? Certamente que a resposta é negativa, pois tal atitude seria contraproducente e antieconômica, mostrando-se injustificável, seja do ponto de vista processual ou mesmo prático. Assim, em casos como o hipoteticamente relatado, mostra-se mais interessante para o ente público a habilitação de seu crédito no processo de falência, aguardando o pagamento dos credores.

Esclarecido o fato de que a execução fiscal não permite à Fazenda Pública iludir a ordem de pagamento dos créditos concursais, sanaram-se, por via de consequência, as dúvidas sobre o pagamento das multas tributárias. Isto porque, conforme leitura dos arts. 83, VII da LFRE e 186, III do CTN, ele somente é realizado após o pagamento dos créditos quirografários. Assim, mesmo que a execução fiscal inclua em sua cobrança as multas, o valor levantado será destinado à composição do ativo da massa, e a ordem de pagamentos será respeitada, separando-se o crédito tributário das eventuais multas.

A escolha entre a habilitação de crédito e a execução fiscal possibilitada pelo Superior Tribunal de Justiça, conforme analisado, representa vantagem ao fisco tão somente para cobrar valores abaixo dos R $\$ 10.000,00$ (dez mil reais), diante da impossibilidade de execução nesses casos. Por outro lado, não restam prejuízos aos demais credores, vez que o prosseguimento das execuções fiscais não implica no desrespeito à ordem de pagamento do concurso de credores, e todo o montante arrecadado em seus autos é destinado à formação do ativo da massa falida.

\section{A (i)legitimidade da Fazenda Pública para pedir a falência de seu devedor}

Conhecida a possibilidade de escolha da Fazenda Pública entre a execução fiscal e a habilitação de crédito, segue-se analisando dispositivos da lei 11.101/05 que sobre ela (Fazenda Pública) incidem e foram objeto da jurisprudência do Superior Tribunal de Justiça. Oportuno se faz, nesse sentido, o debate sobre sua (i)legitimidade para propor a falência do devedor, dúvida que fora alçada à deliberação do STJ sobretudo em virtude do interesse público que fundamenta a atuação fiscal em tais casos.

No Decreto-Lei 7.661/45, as pessoas que podiam pedir a falência do devedor estavam legitimadas pelos arts. $8^{\circ}$ e $9^{\circ}$. Segundo eles, além da possibilidade de a falência ser requerida pelo próprio devedor (autofalência), também podiam pleiteá-la o cônjuge sobrevivente, os 
herdeiros do devedor, o inventariante, o sócio, o acionista ou qualquer credor. Neste último caso, dividiam-se os credores em: i) credor comerciante domiciliado no Brasil; ii) credor com garantia real e; iii) credor não domiciliado no Brasil. ${ }^{7}$

De acordo com tais disposições, a Fazenda Pública somente se encaixaria na hipótese do art. 9, III, “B”, vez que não exercia atividade comercial ou tinha domicílio fora do Brasil, pelo que restou o questionamento sobre sua legitimidade para propor a falência de seus devedores. A dúvida foi levada ao crivo do STJ por meio do Recurso Especial $n^{\circ}$. 10.660, julgado no dia 12 de dezembro de 1995. Sob relatoria do Ministro Costa Leite, entendeu-se que o Decreto-Lei 7.661/45 não fazia qualquer empecilho legal à propositura da falência pela Fazenda Pública, conferindo-lhe legitimidade para tanto. Tal decisão, a bem da verdade, adotou postura juspositivista, aplicando de maneira literal o dispositivo sem que fosse levado em consideração o ordenamento jurídico no qual estava inserido. Segundo Bobbio (1995, p. 142):

\begin{abstract}
O positivismo jurídico, definindo o direito como um conjunto de comandos emanados pelo soberano, introduz na definição o elemento único da validade, considerando, portanto, como normas jurídicas todas as normas emanadas num determinado modo estabelecido pelo próprio ordenamento jurídico, prescindindo do fato de estas normas serem ou não efetivamente aplicadas na sociedade: na definição do direito não se introduz assim o requisito da eficácia (grifos do autor).
\end{abstract}

A Lei 11.101/05, por sua vez, manteve-se na mesma linha de seu antecessor e, por intermédio de seu art. 97, estabeleceu o rol de pessoas que podem requerer a falência do devedor $^{8}$. Apesar de se ter mantido o que dispunha o Decreto-Lei 7.661/45, a questão, ainda na vigência do decreto-lei, foi novamente levada ao julgamento do Superior Tribunal de Justiça, que, desta vez, adotou outro caminho para a solução da controvérsia ao decidir os Recursos

\footnotetext{
${ }^{7}$ Art. $9^{\circ}$ A falência pode também ser requerida: [...]

III - pelo credor, exibindo título do seu crédito, ainda que não vencido, observadas, conforme o caso, as seguintes condições:

a) credor comerciante, com domicílio no Brasil, se provar ter firma inscrita, ou contrato ou estatutos arquivados no registro de comércio;

b) o credor com garantia real se a renunciar ou, querendo mantê-la, se provar que os bens não chegam para a solução do seu crédito; esta prova será feita por exame pericial, na forma da lei processual, em processo preparatório anterior ao pedido de falência se êste se fundar no artigo $1^{\circ}$, ou no prazo do artigo 12 se o pedido tiver por fundamento o art. $2^{\circ}$;

c) o credor que não tiver domicílio no Brasil, se prestar caução às custas e ao pagamento da indenização de que trata 0 art. 20.

8 Art. 97. Podem requerer a falência do devedor:

I - o próprio devedor, na forma do disposto nos arts. 105 a 107 desta Lei;

II - o cônjuge sobrevivente, qualquer herdeiro do devedor ou o inventariante;

III - o cotista ou o acionista do devedor na forma da lei ou do ato constitutivo da sociedade;

IV - qualquer credor.
} 
Especiais n ${ }^{\circ} 164.389$ e 138.868, ambos de Minas Gerais.

Em ambas as decisões, o Superior Tribunal de Justiça optou por modificar os postulados de sua jurisprudência até então predominante e, mesmo diante da ausência de expressa vedação legal ao pedido de falência pela Fazenda Pública, negou-lhe tal possibilidade por não vislumbrar interesse de agir em tais casos, porquanto a cobrança tributária é atividade vinculada, da qual o fisco não pode se recusar.

PROCESSO CIVIL. PEDIDO DE FALÊNCIA FORMULADO PELA FAZENDA PÚBLICA COM BASE EM CRÉDITO FISCAL. ILEGITIMIDADE. FALTA DE INTERESSE. DOUTRINA. RECURSO DESACOLHIDO.

I - Sem embargo dos respeitáveis fundamentos em sentido contrário, a Segunda Seção decidiu adotar o entendimento de que a Fazenda Pública não tem legitimidade, e nem interesse de agir, para requerer a falência do devedor fiscal.

II - Na linha da legislação tributária e da doutrina especializada, a cobrança do tributo é atividade vinculada, devendo o fisco utilizar-se do instrumento afetado pela lei à satisfação do crédito tributário, a execução fiscal, que goza de especificidades e privilégios, não lhe sendo facultado pleitear a falência do devedor com base em tais créditos. (SUPERIOR TRIBUNAL DE JUSTIÇA, 2004, online)

Apesar de tal decisão se ter dado antes da entrada em vigor da Lei 11.101/05, ela reflete razões pelas quais houve a necessidade de criação da nova legislação, sofrendo influência, inclusive, do princípio da preservação da empresa. Como fundamento do acórdão, utilizou-se o interesse de agir, vez que, à época, discutia-se se para contemplar o interesse público era mais importante pedir a falência da sociedade empresária e buscar o pagamento dos tributos devidos ou preservá-la para que ela continuasse ativa, gerando emprego e renda. Nas palavras de Luís Felipe Salomão e Paulo Penalva Santos (2017, p. 274/275):

O instituto da falência surgiu para reprimir a utilização anormal do crédito, cuja finalidade era tão somente patrimonial. Partindo dessa premissa, de que a falência destina-se à preservação do crédito como mecanismo de circulação das riquezas, é possível admitir que o mesmo não foi criado nem é utilizado habitualmente para cobrança de tributos. E, mais ainda, o pedido de falência pelo Fisco pode até mesmo ser considerado abuso de direito, caracterizando, assim, a violação ao princípio constitucional da razoabilidade.

Escolheu-se, conforme visto, o caminho da preservação da empresa, princípio que justificou a elaboração da Lei 11.101/05 e que, mesmo em decisões antes de sua vigência, já era considerado nas decisões proferidas pelo Superior Tribunal de Justiça. Nesse sentido, tirouse da Fazenda Pública a legitimidade para propor a falência de seus devedores, sob fundamento técnico de lhe faltar interesse processual.

Entende-se que, referida interpretação, sem fundamento direto em texto da lei, levou em 
consideração não só pilares que norteiam o direito falimentar, mas disposições da própria ordem constitucional econômica que, dentre seus princípios, elenca a função social de propriedade e a busca do pleno emprego. Tais premissas são garantidas com a manutenção da atividade empresária, e não com seu encerramento (MELO; PEREIRA JR, 2014).

Desta feita, quando ponderada qual medida atenderia em maior grau ao interesse público - se a quitação dos débitos tributários ou a manutenção da atividade empresária - julgou o STJ em favor desta, reconhecendo o ganho coletivo que decorre da produção de bens e serviços no país. Ademais, mesmo que a Lei 11.101/05 não tenha suprido referência expressa ao tema em seu texto, já controverso durante o processo legislativo, a Corte especial se valeu de princípios dela para se posicionar.

\section{A não suspensão da Execução Fiscal e a penhora no rosto dos autos do processo falimentar}

Conforme já sinalizado em tópico anterior, o Código Tributário Nacional, em seu art. 187 e o art. 29 da Lei 6.830/80, estabelece que o crédito tributário não se sujeita a concurso de credores ou habilitação em falência. O que importa dizer que a decretação da falência não impossibilitará o surgimento de novas execuções fiscais, assim como tampouco suspenderá o curso dos processos já ajuizados pela Fazenda Pública.

Divergências doutrinárias e jurisprudenciais surgem quanto à forma de recebimento do crédito da Fazenda Pública, em respeitos aos preceitos estabelecidos no CTN e da LRFE, concomitantemente. Isto porque, apesar de ciente da impossibilidade da dívida da Fazenda Pública se sujeitar ao concurso de credores, nos moldes do art. 29 da Lei 6.830/80 e 187 do CTN , há de se ponderar que tal dispositivo deve ser entendido em consonância com o art. 83 da Lei 11.101/05 , que classifica a ordem de recebimento dos créditos no processo falimentar.

Dois momentos surgem para serem analisados. O primeiro deles quando a execução fiscal é ajuizada em data anterior a decretação da falência, enquanto o segundo quanto esta for proposta em momento posterior. No primeiro caso, já analisado perfunctoriamente no tópico anterior, esta não sofre qualquer sobrestada em decorrência da falência, de modo que, caso tenha ocorrido a penhora, os bens penhorados não serão arrecadados no processo falimentar, 
mas eventual valor arrecadado com o ato expropriatório deverá ser destinado ao juízo falimentar.

Ou seja, a continuidade da execução fiscal não representa uma garantia de que a Fazenda Pública terá seu crédito adimplido para além do concurso de credores, mas que não será necessária a habilitação do crédito já executado. Entretanto, o montante arrecadado na execução fiscal deverá ser disponibilizado para a administração judicial, que fará uso dele para pagar os credores na ordem estipulada na Lei 11.101/05.

O segundo momento a ser analisado, por sua vez, trata-se de quando a propositura da execução fiscal se dá em momento posterior a decretação da falência. Nesses casos têm os tribunais entendido que deverá ser realizada a penhora no rosto dos autos do processo falimentar, de modo que o pagamento dependerá da realização do ativo e da ordem estabelecida na LRFE. Referido entendimento foi sumulado no Tribunal Federal de Recursos (BRASIL, 2017):

\footnotetext{
Súmula 44 - TFR

Ajuizada a execução fiscal anteriormente à falência, com penhora realizada antes desta, não ficam os bens penhorados sujeitos a arrecadação no Juízo falimentar; proposta a execução fiscal contra a massa falida, a penhora far-se-á no rosto dos autos do processo da quebra, citando-se o síndico.
}

Dessa maneira, interessante se faz analisar a natureza jurídica e justificativa da existência do instituto de penhora no rosto dos autos do processo falimentar, em caso de execução fiscal proposta após a decretação da falência, sobretudo considerando-se a efetividade do instituto em comparativo com o concurso de credores, a fim de se demonstrar qual a sua aplicabilidade na prática.

A penhora no rosto dos autos é instituto jurídico que encontra permissivo legal no art. 860 do Código de Processo Civil de 2015 e tem como objetivo resguardar um direito de crédito de uma pessoa física ou jurídica nos autos de outro processo que o devedor tenha eventual crédito a receber. Ou seja, trata-se verdadeiramente de uma compensação de créditos que acontece em vias processuais. Segue abaixo dispositivo processual sobre o tema (BRASIL, 2015):

Art. 860. Quando o direito estiver sendo pleiteado em juízo, a penhora que recair sobre ele será averbada, com destaque, nos autos pertinentes ao direito e na ação correspondente à penhora, a fim de que esta seja efetivada nos bens que forem adjudicados ou que vierem a caber ao executado. 
Tem-se, portanto, que o instituto visa à proteção do crédito, garantindo-se que o produto eventualmente arrecadado judicialmente tenha destinação específica, considerando-se a morosidade do Judiciário e as possibilidades efetivas de êxito de diferentes processos expropriatórios. Sobre o tema da penhora no rosto dos autos esclarece Pontes de Mirada (2002, p.240/241):

\begin{abstract}
Trata-se da hipótese de penhora de direito litigioso que se averba no rosto dos respectivos autos, atingindo bens que corresponderem ao devedor no processo. A penhora no rosto dos autos, que se trata de efetiva penhora e não de meros atos preparatórios, impede a entrega dos bens ou do seu preço ao devedor executado.
\end{abstract}

Saliente-se que a aplicabilidade do instituto da penhora no rosto dos autos em execuções fiscais não encontra amparo jurídico no Código Tributário Nacional, na Lei Execuções Fiscais, tampouco na Lei 11.101/05, sendo uma construção doutrinária e jurisprudencial, a fim de dar uma maior aplicabilidade e resguardo ao recebimento de crédito pela Fazenda Pública no processo falimentar.

Assim, o antigo pronunciamento do Supremo Tribunal Federal no RE 92.488, de 1979, Relatoria do Ministro Cunha Peixoto, ainda permanece atual, pois reconhece que a penhora no rosto dos autos "não viola a lei, pois não impede o curso do executivo, que continua em seu andamento normal, recebendo a Fazenda Pública no final, prioritariamente, do resultado da liquidação da massa. De outro modo, impossível se tornaria a atuação do juízo da falência, cuja unidade seria desfeita de penhoras em bens por ela já arrecadados" (BRASIL, 1979).

Veja-se que além do entendimento da aplicabilidade da penhora no rosto dos autos não ser contra legem, este ainda possibilita a máxima aplicabilidade do princípio do contraditório e da ampla defesa pelo executado na execução fiscal. Isto porque, de acordo com o art. 16 da Lei 6.830 (BRASIL, 1980), o prazo para oferecimento de embargos a execução iniciará da data do depósito, da juntada da prova da fiança bancária ou do seguro garantia, ou da intimação da penhora. Veja-se:

Art. 16 - O executado oferecerá embargos, no prazo de 30 (trinta) dias, contados: I - do depósito;

II - da juntada da prova da fiança bancária;

II - da juntada da prova da fiança bancária ou do seguro garantia; (Redação dada pela Lei $\mathrm{n}^{\circ} 13.043$, de 2014)

III - da intimação da penhora.

$\S 1^{\circ}$ - Não são admissíveis embargos do executado antes de garantida a execução. 


\section{O tratamento diferenciado da Fazenda Pública no Processo Falimentar}

$\S 2^{\circ}$ - No prazo dos embargos, o executado deverá alegar toda matéria útil à defesa, requerer provas e juntar aos autos os documentos e rol de testemunhas, até três, ou, a critério do juiz, até o dobro desse limite.

$\S 3^{\circ}$ - Não será admitida reconvenção, nem compensação, e as exceções, salvo as de suspeição, incompetência e impedimentos, serão argüidas como matéria preliminar e serão processadas e julgadas com os embargos.

Logo, pela exegese da lei, depreende-se que os embargos à execução, via de defesa do executado, só serão admitidos quando realizada a garantia da execução. Ocorre que a massa falida resta impossibilitada de dispor de seus bens para oferecimento das garantias acima expostas, sob pena de inobservância ao princípio do par conditio creditorum, revelando-se imprescindível a expropriação na execução autônoma.

Assim, acaso não fosse o entendimento jurisprudencial quanto à possibilidade de penhora no rosto dos autos ser plenamente aplicável na execução fiscal, a massa falida restaria impossibilitada de se utilizar desta via processual de defesa, ante a sua impossibilidade de oferecer garantia, o que não se mostra razoável sobretudo ante a sua natureza jurídica de patrimônio de afetação.

Diante de todo o exposto, conclui-se que o entendimento jurisprudencial que entende pela aplicabilidade do instituto da penhora no rosto dos autos da falência em execução fiscal se mostra adequado aos interesses da Fazenda Pública, porquanto possibilita que esta resguarde o recebimento de seu crédito no próprio processo falimentar, tratando-se de efetiva penhora. Referido entendimento também se harmoniza com os interesses do executado (massa falida), pois possibilita a utilização da via de defesa dos embargos à execução, instrumento processual que não seria aplicável à massa falida ante a impossibilidade de oferta de garantia descrita na Lei de Execuções Fiscais.

\section{Conclusão}

Ao longo do presente estudo, buscou-se analisar quais são as prerrogativas previstas em lei para tratamento diferenciado da Fazenda Pública quando esta ocupa a posição de credora em processos de falência. Para tanto, buscou-se apresentar a legislação concernente ao tema, tanto específica à Fazenda Pública, sobretudo o Código Tributário Nacional, quanto aquela que regula o processo falimentar.

Identificou-se, nesse sentido, que a legislação sobre a matéria falimentar, em consonância com as disposições do CTN, concedeu certos privilégios à Fazenda Pública em 
referidos casos. De início, tem-se a posição privilegiada na qual ela se encontra quanto aos demais créditos, encontrando-se abaixo tão somente dos créditos trabalhistas (limitados por valor) e dos créditos com garantia real, fazendo-se ainda a ressalva da grande discussão quanto à sua mudança de posição e suposta perda de privilégio.

Em complemento à legislação falimentar, foram estudadas outras prerrogativas do Fisco dentro do processo falimentar, a exemplo de sua possibilidade de escolha entre a habilitação de crédito e a execução fiscal, pelo que ele pode ponderar sobre a viabilidade e a contingência em ambos os casos para, deliberadamente, optar por aquele caminho que lhe for mais conveniente.

Referido entendimento, construído pela jurisprudência consolidada do Superior Tribunal de Justiça, revela o interesse jurídico que há em se privilegiar um crédito que, por sua natureza, tem repercussão social. Não obstante, tais garantias não dão privilégios infinitos à Fazenda Pública, que não terá a possibilidade de propor os dois cumulativamente, devendo optar entre um deles.

Apesar de poder fazer referida escolha, a Fazenda Pública não se sobrepõe à ordem do concurso previsto em lei. Assim, ainda que lhe seja possibilitada a opção, ela estará adstrita ao concurso conforme dispõe a legislação falimentar, significando dizer que sua possibilidade de escolha diz muito mais à condição que ela, dentro de uma execução fiscal, disporá de buscar eventuais bens do devedor.

Considerada a natureza de seu crédito, viu-se também que o Fisco não possui legitimidade para propor as ações falimentares. Afinal, ainda que o interesse da Fazenda Pública seja o de arrecadação de ativos, sopesando-se a repercussão social negativa e a ausência de garantia de recebimento de valores dentro do processo falimentar, viu-se que os prejuízos decorrentes de uma falência seriam maiores que o ganho do fisco com sua decretação.

Assim, por construção jurisprudencial e afirmação doutrinária, optou-se por retirar da Fazenda Pública a legitimidade ativa para a propositura de ação falimentar. Foi por essas mesmas fontes - doutrina e jurisprudência - que ficou estabelecida a possibilidade de penhora no rosto dos autos decorrentes de execuções fiscais, privilegiando-se uma vez mais o Fisco em tais ações.

Verifica-se, portanto, que legislação, doutrina e jurisprudência convergem quanto à 
concessão de privilégios para o Fisco em processos falimentares, sobretudo pela relevância pública que tais créditos detêm. Por outro lado, viu-se que em situações nas quais a repercussão social se encontra acima do pagamento de dívidas fiscais, a exemplo da própria decretação da falência (na qual, reitera-se, não há garantia alguma de pagamento), privilegiou-se a preservação da atividade empresarial.

Tal entendimento encontra-se acertado, sobretudo porque será a preservação da atividade que, a longo prazo, gerará retorno social, dispondo o Fisco de outros meios para a satisfação de seu crédito (inclusive, como visto, a própria possibilidade de eleição da medida a ser adotada, se a habilitação do crédito ou a execução fiscal), revelando-se o interesse do ordenamento jurídico em privilegiá-la, fato que, a rigor, não traz qualquer prejuízo à ordem estabelecida por lei.

\section{Referências}

BOBBIO, Norberto. O Positivismo Jurídico: Lições de filosofia do direito. São Paulo: Ícone, 1995. Tradução de Márcio Pugliesi, Edson Bini e Carlos E. Rodrigues.

BRASIL. Lei no 5.172, de 24 de outubro de 1966. Dispõe sobre o Sistema Tributário Nacional e institui normas gerais de direito tributário aplicáveis à União, Estados e Municípios.

Disponível em: <http://www.planalto.gov.br/ccivil_03/leis/15172.htm>. Acesso em: 09 abr. 2018.

. Lei $n^{\circ} 6.830$, de 22 de setembro de 1980. Dispõe sobre a cobrança judicial da Dívida

Ativa da Fazenda Pública, e dá outras providências. Disponível em:

<http://www.planalto.gov.br/ccivil_03/leis/16830.htm>. Acesso em: 09 abr. 2018.

. Lei $\mathrm{n}^{\circ}$ 13.105, de 13 de março de 2015. Código de Processo Civil.

. Supremo Tribunal Federal. Re n ${ }^{\circ}$ 92.488. Relator: Ministro Cunha Peixoto. Diário

Oficial da União. Brasília, . Disponível em:

$<$ https://stf.jusbrasil.com.br/jurisprudencia/913475/recurso-extraordinario-re-92488-rj/inteiroteor-100592827?ref=juris-tabs\#>. Acesso em: 09 abr. 2018.

. TFR. Súmula no 44. Brasília, 18 de dezembro de 2017. Execução Fiscal. Penhora Anterior à Falência. Bens Não Sujeitos Ao Juízo Falimentar. Ctn, Art. 187. Decreto-lei 858/69, Art. 2 o. Lei 6.830/80, Art. 29 .. Disponível em:

$<$ https://www.legjur.com/sumula/busca?tri=tfr\&num=44>. Acesso em: 09 abr. 2018.

. Lei Ordinária $n^{0} 11.101$, de 09 de fevereiro de 2005. Regula a recuperação judicial, a extrajudicial e a falência do empresário e da sociedade empresária. Lei no 11.101, de 9 de Fevereiro de 2005. Brasília, DF, 09 fev. 2005. Disponível em: $<$ http://www.planalto.gov.br/ccivil_03/_ato2004-2006/2005/lei/l11101.htm>. Acesso em: 25 jan. 2016.

Projeto de Lei da Câmara no 71. Brasília, DF, 2003. Disponível em: 
<http://www25.senado.leg.br/web/atividade/materias/-/materia/63304>. Acesso em: 25 jan. 2016.

Superior Tribunal de Justiça. Recurso Especial nº 1.103.405/MG. Relator: Ministro Castro Meira. Brasília, DF, 02 de janeiro de 2009. Diário de Justiça Eletrônico. Brasília, 27 abr. 2009. Disponível em:

$<$ http://www.stj.jus.br/SCON/jurisprudencia/doc.jsp?livre=1103405\&b=ACOR\&p=true\&t=J URIDICO\&l=10\&i=2>. Acesso em: 22 maio 2016

Superior Tribunal de Justiça. Acórdão n 164.389/MG. Relator: Ministro Castro Filho. Brasília, DF, 13 de janeiro de 2003. Diário de Justiça Eletrônico. Brasília, 16 ago. 2004. Disponível em:

$<$ http://www.stj.jus.br/SCON/jurisprudencia/doc.jsp?processo=164389+\&b=ACOR\&p=true \&

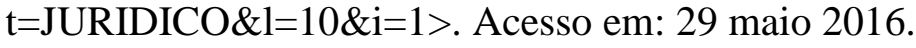

LIMA, Jonatas Vieira de. A posição do crédito tributário no procedimento falimentar à luz do CTN e da Lei 11.101/2005. In: Âmbito Jurídico, Rio Grande, XV, n. 105, out 2012.

Disponível em:

<http://ambitojuridico.com.br/site/index.php/?n_link=revista_artigos_leitura\&artigo_id=1194 3\&revista_caderno $=26>$. Acesso em maio 2016

MAMEDE, Gladston. Direito empresarial brasileiro: falência e recuperação de empresas. 9. ed. São Paulo: Atlas, 2018.

MELO, Renan Wanderley Santos; PEREIRA JUNIOR, Antonio Jorge. A tríplice dimensão da preservação da empresa. In: CONPEDI. XXIII Encontro Nacional do CONPEDI/UFSC: Livro de Direito Empresarial. Florianópolis: Conpedi, 2014. p. 303-317. Disponível em: <http://www.publicadireito.com.br/artigos/?cod=3d654477886f3204>. Acesso em: 06 ago. 2016.

MIRANDA, de Ponte. Comentários ao Código de Processo Civil. Tomo X. Rio de Janeiro, Forense, 2002.

SALOMÃO, Luis Felipe; SANTOS, Paulo Penalva. Recuperação judicial, extrajudicial e falência: teoria e prática. 3. ed. Rio de Janeiro: Forense, 2017.

TOLEDO, Paulo F.c. Salles de; ABRÃO, Carlos Henrique. Comentários à Lei de

Recuperação de Empresas e Falência. 5. ed. São Paulo: Saraiva, 2012. 